\title{
Intervening in a Diverse World: Revisiting the 'Problem' of Difference in International Statebuilding
}

\section{Authors and affiliation:}

Pol Bargués-Pedreny, Barcelona Centre for International Affairs, pbargues@cidob.org Xavier Mathieu, Aston University, x.mathieu@aston.ac.uk

Biographies:

Dr. Pol Bargués-Pedreny is a research fellow at the Barcelona Centre for International Affairs, working on the Horizon 2020 project on EU's external action (EULISTCO). He has developed an interest in the intersection of philosophy and international relations. His work explores debates of international interventions and critically interrogates perspectives on resilience, hybridity and social critique. He is author of Deferring Peace in International Statebuilding: Difference, Resilience and Critique (Routledge 2018) and co-editor of Mapping and Politics in the Digital Age (Routledge 2018)

Dr Xavier Mathieu is a Teaching Associate at Aston University and was previously a post-doctoral fellow at the Centre for Global Cooperation Research (University of Duisburg-Essen). He holds a PhD from the University of Sheffield. His research interests include the theory and practice of sovereignty, peacebuilding, civilisational politics and the theorising of 'difference' in international interventions. He has published articles on these topics in International Relations, Journal of International Political Theory, Third World Quarterly and the Journal of Intervention and Statebuilding.

\begin{abstract}
Can the pessimism regarding the possibility to support statebuilding in a diverse world be reversed? In this chapter we argue that the current miasma of despair regarding international interventions is the result of three successive errors: silencing, problematizing and stigmatising cultural difference. After examining these three errors, we suggest three new starting points: approaching difference as multidimensional, refusing to essentialise difference, and focusing on the power relations that make difference exist in the first place. By putting 'difference' centre stage, our ambition is to reveal new analytical strategies that go beyond the impasse in which the field of statebuilding finds itself.
\end{abstract}




\section{Introduction}

How may international statebuilding work in a diverse world? How do differences impact on peace processes in fragile states? International statebuilding as a practice and academic field has always been embroiled in the 'problem' of difference. Since the late 1990s, socio-cultural differences have been identified both as the origin of conflicts and as essential to consolidate peace (Avruch 1998; Lederach 1997; Miall, Ramsbotham, and Woodhouse 1999). International organisations have gradually paid attention to the informal settings of societies intervened upon as spheres where differences are reproduced and the seeds of war and peace can be found. Even statebuilding frameworks, which tend to focus on the creation of legitimate governmental institutions and market reforms from 'the top-down', have become more willing to adjust to the diversity of local contexts (Ingram 2010, OECD 2012). In the twenty-first century, it has become a platitude to admit that peace processes that are not led by local actors and respectful of their traditions and mores often go awry. Yet, policymakers express pessimism about the possibility to engage with difference successfully so that a contextsensitive peace can be attained. Sometimes cultural practices and societal codes seem difficult to comprehend to the external gaze, other times they seem incompatible with the aims of building peace.

In the scholarly literature, particularly within critical circles, the consensus is that international interventions have mostly failed because of the very superficial attention given to the diverse needs, values and experiences found in post-conflict societies (Kappler 2015, Mac Ginty and Firchow 2016). Liberal programmes of conflict-resolution and statebuilding have been met with resistance from local traditions, identities and cultures. Critical reappraisals have thus argued for interventions that are respectful of local contexts and histories and connected with 'everyday' practices. Yet the limits of this turn to the local - such as the tendency to reproduce simplistic binaries - have been widely recognised (Chandler 2010; Nadarajah and Rampton 2015; Randazzo 2016). As Meera Sabaratnam has it, even in critical frameworks of statebuilding cultural difference is often reduced to 'the liberal/ local distinction [that] appears to be the central ontological fulcrum upon which the rest of the political and ethical problems sit' (Sabaratnam 2017, 29 , original emphasis). In sum, whereas practitioners and mainstream approaches worry about their inability to fully 'capture' difference or manage it in a way that is conducive to peace, critical scholars worry about the inability to 'write' difference without essentialising 'it' or reproducing and legitimising power structures. As difference seems fundamentally elusive, scholars and practitioners increasingly admit that the Other cannot be helped and that any statebuilding strategy that attempts to be sensitive to difference is doomed (Bargués-Pedreny 2017).

The problem of cultural difference can thus be considered as central in the field of 
statebuilding (see Brigg 2008, Behr 2014 and Mathieu forthcoming). In this chapter, we argue that a sustained attention to the theorisation, emergence and ambiguities of difference can shed light on some of the problems faced by statebuilding research and practice. We propose to look at international interventions in war-peace transition states through the lens of difference to clarify and help solve some of the deadlocks faced by contemporary scholars and practitioners. Our aim is twofold:

Firstly, we argue that the miasma of despair regarding difference and statebuilding is the result of three successive errors that occur when dealing with difference in international interventions: silencing, problematizing and stigmatising difference. We explain how statebuilding approaches have been (re)producing these three errors and thus limiting our ability to engage with difference productively. Secondly, we outline three analytical starting points to think about difference differently: multidimensionality, anti-essentialism, and a focus on difference as an expression of power relations. These three options open up new ways of approaching the issue of cultural difference; by putting 'difference' centre stage, our ambition is to reveal new analytical strategies that go beyond the impasse in which the field of statebuilding finds itself.

\section{From Undervaluing to Overvaluing Cultural Difference}

The work of Kevin Avruch is useful to frame the dilemma around difference that confronted international interventions throughout the 1990s and 2000s. As an anthropologist preoccupied with conflict resolution, Avruch (1998) criticised theories and practices that rendered culture and cultural differences trivial. For him, 'undervaluing culture' is the first type of error in traditional conflict resolution practices. These practices, he explained, tend to focus on rational negotiations between the representatives of disputing parties, as if context, values, traditions, or ethnic differences played no role for participants in a conflict. Initially, thus, Avruch could be read as pointing towards the championing of culture as an important element for understanding conflict and its resolution. However, Avruch does not suggest that we should talk about or emphasise culture unhesitatingly, with no holds barred, when addressing a cultural dispute. There is a second type of error which surfaces in the process of trying to correct the first: the tendency to 'overvalue culture' by 'overestimating its impact on a conflict' (Avruch 2003, 363). Overemphasising culture is essentially harmful to some parties in a conflict already saturated with cultural animosities because, Avruch contends (2003, 367), it homogenises, essentialises and reinforces particular forms of identity while neglecting or delegitimising others. We re-read the history of the field through Avruch's two errors to argue that throughout much of the 1990s scholars and practitioners involved in post-conflict recovery erred because they generally undervalued culture, whereas in the 2000s the tendency was to recognise it but characterise it as an obstacle to 
consolidate peace. For heuristic reasons, this 'history' of statebuilding is presented in a linear fashion. In reality, however, the errors have co-existed and still do.

The first error is most explicit in the early international peace support interventions. Indeed, in these interventions cultural differences were not considered as important since every society was seen as willing and capable of democratising in a similar way (Doyle 1986; Fukuyama 1992; Huntington 1991). Differences among societies did certainly exist, but they represented the different stages of a universal and linear progression towards liberal democracy. Universal logics - such as actors interacting rationally in a perfectly predictable world - drove international relations, providing a convincing explanation for the deviations or delays of some local cultures (Lapid and Kratochwil 1996; Valbjørn 2008, 57-59). However, uncomfortable questions soared as peace proved difficult to consolidate in many non-Western states throughout the 1990s. If democracy and free markets were a source of peace and progress, why had some countries in transition to democracy failed to stabilize? Why had liberal multiculturalism been key to manage diversity and promote cultural rights to minorities in most Western states but failed as soon as it was exported elsewhere (Eller 1999; Kymlicka 2001)? Why was it so onerous to expand the liberal democratic zone of peace?

In debates assessing the difficulties of democratization, liberalization and peacebuilding in the aftermath of civil wars in the non-West, the notion of difference appeared as a problem to be considered. The fact that democratisation and economic liberalisation were successful in the West but failed to stabilise countries emerging from armed conflict in the non-West led to the perception that non-Western societies possessed specific traits that hindered their progress. Crucially, difference between human beings was expressed by referring to the inward and unconscious attributes of societies - their 'culture' or psychosocial characteristics - and came to be a key explanatory variable for the failure of allegedly universal policy solutions (Pupavac 2001). International interventions had thus been guilty of the first type of error identified by Avruch: they had ignored the relevance of culture and assumed that all societies would transform into peaceful liberal democracies.

The focus on cultural differences thus revealed a feeling of growing disenchantment with universal values and approaches with worldwide pretensions. Scholars increasingly recognised not only that psychosocial factors had decisive effects on conflicts, but also that these could not be overlooked in peace processes (Avruch 1998; Avruch and Black 1991; Lederach 1997; Miall, Ramsbotham, and Woodhouse 1999). International interventions began to evolve from a concern with the formal and political sphere of societies to the regulation of the more informal settings where differences and inequalities among societies were reproduced over time (Chandler 2010). For example, at the end of the 1990 s civil society became a key preoccupation of programmes of 
international intervention. It was understood as an informal space beyond the state which had to be technically assisted and empowered in order to achieve tolerance and sustainable peace (see Gabay and Death 2012).

This emphasis on difference in intervention programmes was considered a step forward when compared to earlier operations that had worked from a one-size-fits-all peace model and ignored local histories, knowledge and mores. In moving from strictly military and security dimensions to the broader social and cultural contexts of conflictaffected societies, statebuilding processes (with an emphasis on a comprehensive institutional strengthening) appeared apt to address the root causes of conflicts and facilitate psychosocial healing and long-term reconciliation (Lederach 1997, 24-35; Miall, Ramsbotham, and Woodhouse 1999, 206-15). Moreover, exhibiting cultural sensitivity in post-war scenarios was motivated by a normative commitment to respect diverse traditions at a time when Western countries were generally favouring multiculturalism, rather than assimilation, in domestic politics.

Nevertheless, a new problem appeared in statebuilding processes: by emphasising the need to protect and cultivate identities and differences, international interventions were guilty of legitimising and replicating ethno-nationalist perspectives and warantagonisms (Campbell 1998, 88-93; Valbjørn 2008, 64; Vaughan-Williams 2006, $517-$ 18). Thus a second type of error haunted peace interventions in the context of the 'cultural turn': as Avruch had warned, peace practitioners quickly realised that overvaluing culture brings as many problems as it solves.

Through much of the 2000s, internationally-led statebuilding missions sought to find a solution to avoid the two errors: on the one hand, external actors could not ignore the primacy of those psychosocial factors that had influenced the history and development of the countries intervened in; on the other hand, they could not concede too much to local actors and cultures and fuel the same identities and disagreements that had caused the turmoil. A tertium quid was required that took the form of a 'pragmatic tolerance' in which difference was valued insofar as it had a positive role for building peace. Thus peace missions adopted an unstable middle-ground position in which they would respect difference when seen as not obstructing the non-negotiable goals of stability, the rule of law and economic liberalism. Statebuilding frameworks, for example, can be said to be paradigmatic of a position that admitted the importance of culture in societies intervened in but considered it an obstacle that had to be managed, regulated and assimilated through a process of institution-building (Chesterman, Ignatieff, and Thakur 2005; Ghani and Lockhart 2008; Paris and Sisk 2009). In the field of policy practice, the emphasis on strengthening institutions was translated into a top-down strategy to transform the perceptions, beliefs and other socio-cultural pathologies of the people, so that they could learn to iron out their differences without resort to arms. The 
Weberian state became the fulcrum of all statebuilding projects, against which differences were censured if they deviated too much from universal norms (LemayHébert and Mathieu, 2014). Even Avruch, who carried the torch of cultural sensitivity during the 1990s, became cautious not to include (and overvalue) some cultural traits when these hindered the goal of solving a conflict (for a critique, see Brigg and Muller 2009).

Statebuilding projects spread but they did not win the day, as they ended up privileging the position of international agencies and foregrounding external values and models for peace resolution. While they recognised the importance of difference in processes of statebuilding, they reduced most differences to obstacles to be managed, corrected and overcome so that the rule of law, state institutions and markets could be consolidated. In this sense, they reproduced what Antony Anghie (2005: 4) has called the 'dynamic of difference': 'the endless process of creating a gap between two cultures, demarcating ones as 'universal' and civilized and the other as 'particular' and uncivilized, and seeking to bridge the gap by developing techniques to normalize the aberrant society'. If the first error had been to neglect those socio-cultural attributes that may affect the progress of peace consolidation, the second was to consider difference a barrier to the ends of external agencies.

\section{Another Error: Stigmatizing Difference}

As liberal peace projects lost impetus (Campbell, Chandler, and Sabaratnam 2011), however, demands for approaches more sensitive to difference bourgeoned. Over the last ten years scholars have started to explain the poor record of international interventions by highlighting their insufficient understanding of, and engagement with, local histories and cultures (Björkdahl and Gusic, 2015, Lidén, Mac Ginty et al., 2009, Mac Ginty, 2015, Mac Ginty and Richmond, 2016). This deficit, critics argue, is clear in strategies that promote 'local ownership'; indeed, external actors have frequently transferred power to the national groups that seem to adjust to liberal norms while disregarding other actors that are less donor-darlings (Lee and Özerdem, 2015). As a solution, scholars stress the need to engage more respectfully and genuinely with the culturally-different local, involving minorities as well as rural and other marginalised actors (Paffenholz, 2014).

These critical approaches infer that peace needs to be fostered 'from below'; they are thus necessarily more open to 'local-local actors', 'infrapolitical' dimensions and indigenous 'resistance' to foreign interventions (Richmond 2012, 116-127). Some scholars suggest replacing the technocratic and distant approach of the liberal peace with 'ethnographic methods' that attend to local experiences and perceptions of conflict and 
peace in order to give a better account of these perplexing dynamics (Millar 2018). Others suggest developing positive forms of 'hybrid peace' in which 'international' and 'local' actors shape and participate in a localised process of peacebuilding (Mac Ginty and Richmond 2016). In these approaches, difference is not understood as culture, for culture is often tinged with reductionism and simplicity, but as the parapraxes, contingencies and twists that make the everyday life of a society unique.

Critical statebuilding scholars have thus called for renewed attempts to engage with difference beyond the universalist assumptions characteristic of previous approaches. This implies a move beyond the second type of error outlined above: if difference was recognised, it was too quickly turned into a problem to be solved by assimilation. In contrast, critical scholars argue that difference has a role to play in building peace; whether this role is positive or negative depends on the circumstances and should not be judged a priori by external actors or measured against universal standards. These approaches therefore outline a third way to consider difference in the context of international interventions: beyond ignorance and problematisation (both leading to assimilation), difference is retrieved as indispensable for building peace.

This third way, however, brings in a new type of error that can be explained by referring to the 'dilemma of difference' introduced by Martha Minow (1990). For Minow, when trying to correct the inequalities suffered by a different person, one can erase and ignore difference in an attempt to equalise all actors (a 'solution' that tends to reproduce the hierarchy it was designed to correct) or, conversely, one can try to adapt to the characteristics of the different person. This second option, seemingly more tolerant, necessitates the identification of what difference is. Yet as Minow argues difference never exists on its own: it becomes visible (and comes into being) only through specific normative frames and expectations. As feminists have argued, for instance, women are only different insofar as the reference point is and remains men. The different person is identified by opposition to what/who is identical (and thus equal). As a consequence, this attempt to respect and value difference necessitates its identification, which in turn can only be achieved by reproducing the normative structures through which the different person was - and therefore remains - inferior.

Two consequences follow from this third error: difference is reified and essentialised and appears inescapable (for a critique, see Sabaratnam 2017, Nadarajah and Rampton 2015), but it is also stigmatised (as a deviance from the 'normal' that is reproduced by the frames used to identify it). For instance, difference is often associated with 'informal institutions' or 'tradition'; yet these 'characteristics' only become salient through the use and acceptation of a specific normative frame influenced by Western perceptions of the 'normal'. In this frame, difference is identified in relation to what the Self believes bimself to be. As such, emphasising difference (even as something to be 
celebrated or as a space from where bottom-up peace initiatives can spring) does not remove the stigma attached to it insofar as what passes for 'normal' cannot be questioned nor made explicit.

Despite the fact that critical scholars strive to treat difference on an equal footing and refuse to prejudge the value of difference, the stated goal of integrating difference for the purpose of peace- and statebuilding appears counterproductive. In fact, the possibility of capturing difference 'on its own terms' has been largely acknowledged as unsuccessful. Recent research on statebuilding has deplored this state of affairs (Sabaratnam 2017, Simons and Zanker 2014, Kappler 2015, Hirblinger and Simons 2015, Paffenholz 2015, and Randazzo 2016), but their conclusions often seem to continue and give new lease of life to the line of investigation that characterises the critics of statebuilding. Indeed, they often urge - again - for more sensitivity towards the particularities and intricacies of societies intervened in.

In sum, these three errors limit the capacity of statebuilding practitioners and scholars to engage with other societies on an equal footing, and miss the opportunity to understand the conditions under which difference emerges. The first error silenced difference as irrelevant due to the force of universalist convictions. With the second error, difference was considered an obstacle that external interventions needed to correct, manage and control. Trying to move away from these two errors, academics and practitioners have sought to reveal difference on its own terms and use it as a basis for peace consolidation. These attempts, however, are limited by the lack of reflection and understanding of the conditions that make difference exist in the first place. Despite their generous starting points, the result is the reproduction of the stigma attached to difference (see, further, Mathieu forthcoming).

\section{Rethinking Difference and the Conditions of its Emergence}

Facing these dilemmas and contradictions, how is one to approach difference? Instead of ignoring, problematizing, or asking for more detailed explorations of what difference is, we suggest focusing on three dimensions that have so far remained underexplored: difference as a multidimensional reality performed in multiple ways and contexts, as a vital yet non-essentialisable feature of human cultures, and linked to power relations. While we do not claim to introduce a new comprehensive statebuilding framework, we maintain that focusing on these three dimensions can shed new light on the issue of difference and help addressing some of the dilemmas faced by scholars and practitioners.

First, against the desire to reduce differences to objective realities existing 'out there', the feminist and queer literatures offer a useful corrective (Butler 1990, 1993; Parker and Kosofksy Sedwick 1995). For them, actors perform their identity through discourses and 
practices. Subjects come into being (and enact their differences) through the reiterated performance of their identity. Expressed differently, it means that the foundations to which discourses and practices of identification refer to in statebuilding - 'traditions', 'modernity', 'history', 'indigeneity', 'local authenticity', 'international (scientific) expertise' - do not pre-exist their performance. This radical re-conceptualisation of identity and difference may change the goals of critical scholars: the objective is no longer to discover the 'real' identity of actors - in order to transform them or to adapt international interventions to their context - but to understand how actors react to, enact and exceed regimes of identity (Read 2018). Drawing attention to the performativity of difference also means recognising that differences are always situated, embodied, scaled, and imbued with meanings that depend on discourses and socio-economic structures (Hirblinger and Landau, 2018; Martin de Almagro 2018).

In fact, recognising the performative aspect of differences also means that identities are inherently multidimensional - even if often reduced to one form of 'difference' (ethnic, religious, gender...) to the exclusion of all others. Recognising these forgotten dimensions could help us cross the boundaries between self and other and cultivate the points of connection and overlap that exist between supposedly different actors acknowledging the 'others that always live within' (Inayatullah and Blaney, 2004: 44) - in order to make advances for peace. The idea of multidimensionality is useful in that regard, yet such recognition can be difficult to attain in a context where the act of othering helps people manage their fears about 'glimpses of dependence and “difference” in themselves' (Minow, 1990: 378).

Second, rather than seeking to represent or use differences to sustain peace, scholars may insist on the irreducible character of identities. This position dwells on deconstructive sensitivities that highlight the irresolvable paradoxes implicated in attempts to make justice to difference: on the one hand, there is a need for a decision or an action to assist the other; on the other hand, any effort to do so will be insufficient (Connolly 2002; Critchley 1992). The consequence of confronting these paradoxes is not stasis or utter impotence. Instead, deconstructive logics bring forward an unstable approach that affirms contradictory impulses while avoiding ultimate foundations. For instance, Paipais (2011: 140) embraces this instability in order to solve the problem of assimilating difference:

What is, perhaps, more important than seeking a final overcoming or dismissal of the self/other opposition is to gain the insight that it is the perpetual striving to preserve the tension and ambivalence between self and other that rescues both critique's authority and function.

If the task of defining and fixing difference becomes impossible, it is a never-ending process that is privileged over closure and conclusions. 
This is reminiscent of the argument made by David Campbell, who, writing against dominant understandings of international intervention in Bosnia, defends 'an ongoing political process of critique and invention that is never satisfied that a lasting solution can or has been reached' $(1998,242)$. Campbell suggests practicing a double task of attending indigenous needs, values and morals, while acknowledging the limits implicated in these undertakings. Other authors have similarly underlined the need for an engagement towards difference (and not with or of difference), holding an infinite predisposition to negotiate its constitution (Behr, 2014: 140). In statebuilding contexts, this implies de-essentialising identity politics and narratives of 'us' and 'them', in parallel to cultivating non-essentialist understandings of peace and difference (Behr 2018).

Yet this position can also be questioned, for not all that is processual and contingent is positive, and that which is discrete and entrenched is negative (for a critique, see Bargués-Pedreny 2018). It may be that the apparent refusal to identify difference in international interventions is not emancipatory, but instead reinforces or aligns with the powers that be. As Orjuela (2008: 248) explains, deconstructing identities is sometimes used as a weapon of domination if it serves to denounce as 'fake' or 'inauthentic' the identity of the marginalised. Moreover, deconstructive logics applied to identity are often restricted to an academic and privileged position constructed above (identity) politics. Indeed, when faced with the necessity of making advances for peace, doing away with identities and differences rarely seems a viable option (Lottholz 2018). Trying to 'solve' the problem of reifying differences by engaging in a never-ending process of blurring them provokes disorientation to practitioners and a deep frustration to local people claiming peace here and now.

A potential corrective to the limits of deconstruction in post-war settings could lie in a position that gives primacy to identities and differences in particularly situated contexts, both recognising their relevance and their ephemeral character. For example, Martin de Almagro (2018) develops the notion of 'hybrid clubs', where actors can perform their 'membership' to a variety of clubs without being essentially attached to them. Their difference is thus fluid and changing. Similarly, Brigg (2018) conceptualises difference as essential to life itself but not in a 'substantialist' way. This is not to deny that difference can appear (and be presented) in essentialist terms by the actors themselves. Such a process can happen through 'strategic essentialism' (see for instance Krishna 1993; Inayatullah 2016) where actors naturalise their identity and difference as existing 'objectively', that is, outside of the worldview that made them salient in the first place. Yet it remains for the scholar to adopt a sceptical perspective by showing how these differences remain politically constructed.

Third, the ontological status of difference can be reconceptualised. Indeed, most research is built on the assumption that difference is empirically discoverable, identifiable 
and thus 'out there'. This common (mis)conception is shared by the three perspectives examined earlier, which assume that difference can be identified in post-conflict societies or that difference is attached to the actors themselves. Thus, and as Maynard (2001: 310) argues, using difference as an 'organising concept' can separate actors from one another and obscure the relationships in which they are engaged (and that make them different).

As a response to this danger, scholars from a diversity of disciplines have shown how difference is a result of (power) relations. For instance, Minow discusses how differences lie between people and not within them. She argues that 'difference expresses patterns of relationships, social perceptions, and the design of institutions made by some without others in mind' (Minow, 1990: 79) instead of essential and discrete characteristics of some people. Similarly, in anthropology, Abu-Lughod (1991: 147) explains that difference 'tends to be a relationship of power'. This means that differences are always the result of political and historical processes emerging from a particular economy of power (Escobar, 2008: 203): in each situation, and out of the almost infinity of traits that characterises every actor, only some are portrayed as differences.

Recognising difference as an expression of power means paying attention to the worldview(s) that powerful actors promote. As Brigg (2008: 11) points out, 'Much of what is at stake in the difference challenge relates, in other words, to different versions of truth and reality'. Only through these worldviews does difference emerge (usually as deviance or anomaly). Ignoring or silencing power - as was done in the universalist as well as in some of the recent stigmatising approaches - is no longer viable. Similarly, identifying differences as problems to be corrected becomes illogical insofar as these differences are created by those seeking to solve them.

Understanding difference as a relation of power linked to specific worldviews impacts frameworks and practices that seek to integrate difference or use it as a resource to consolidate peace. In particular, the central questions are transformed: one no longer asks who is different but rather how difference has been constructed in reference to a specific worldview sustained by a particular economy of power. Bernath (2018), for instance, explores the construction of victim identities in Cambodia with reference to the powerful frame of 'genocide' and how specific differences are entrenched in the process. Framings and inscriptions of identities and differences must be approached with caution, as they entrench some worldviews and erase alternatives; they can help solve conflict as much as reinforce it. Studies must reflect the specific socio-historical contexts and structures that give meaning to identity relations (Joseph 2018).

In conclusion, the three paths detailed here represent an attempt to move beyond the three errors that characterise statebuilding research and practice: silencing difference, considering it an obstacle or stigmatising it. Instead, we suggest exploring difference as it 
is performed in multiple contexts, as that which cannot be arrested but remains essential to life, and as a reflection of broader inequalities of power. This invitation may enable renewed discussions about cultural difference and open the way for reversing the pessimism about international statebuilding. As such, it is also an invitation to have a conversation about how to engage with difference in a non-hierarchical way.

\section{References}

Abu-Lughod, L. (1991). "Writing against culture". Recapturing Anthropology: Working in the Present. R. G. Fox. Santa Fe, NM, School of American Research Press: 137-162.

Anghie, A. (2005). Imperialism, Sovereignty and the Making of International Law. Cambridge, Cambridge University Press.

Avruch, Kevin, and Peter W. Black. 1991. “The Culture Question and Conflict Resolution.” Peace \& Change 16 (1): 22-45.

Avruch, Kevin. 1998. "Culture and Conflict Resolution." Washington: US Institute of Peace Press.

Avruch, Kevin. 2003. "Type I and Type II Errors in Culturally Sensitive Conflict Resolution Practice." Conflict Resolution Quarterly 20 (3): 351-371.

Bargués-Pedreny, P. (2018) Deferring Peace in International Statebuilding: Difference, Resilience and Critique (London: Routledge).

Bargués-Pedreny, P. (2017) "Connolly and the never-ending critiques of liberal peace: from the privilege of difference to vorarephilia." Cambridge Review of International Affairs 30 (2-3): 216234.

Behr, H. (2014). Politics of Difference: Epistemologies of Peace. London and New York, Routledge.

Behr, H. (2018), "Peace-in-Difference: A phenomenological approach to peace through difference", Journal of Intervention and Statebuilding 12 (3): 335-351.

Bernath, J. (2018), "The Politics of Difference in Transitional Justice: Genocide and the

Construction of Victimhood at the Khmer Rouge Tribunal", Journal of Intervention and Statebuilding 12 (3): 367-384.

Björkdahl, A. and I. Gusic (2015). "'Global' norms and 'local' agency: frictional peacebuilding in Kosovo." Journal of International Relations and Development 18(3): 265-287.

Brigg, M. (2008). The New Politics of Conflict Resolution Responding to Difference. Basingstoke, New York, Palgrave Macmillan.

Brigg, Morgan, and Kate Muller. 2009. "Conceptualising Culture in Conflict Resolution." Journal of Intercultural Studies 30 (2): 121-140.

Brigg, Morgan. 2010. "Culture: Challenges and Possibilities." In Palgrave Advances in Peacebuilding: Critical Developments and Approaches, edited by Oliver P Richmond, 329-346. London: Palgrave.

Brigg, M. (2018), "Relational and Essential: Theorizing Difference for Peacebuilding", Journal of Intervention and Statebuilding 12 (3): 352-366.

Butler, J. (1990). Gender Trouble: Feminism and the Subversion of Identity. New York - London, Routledge.

Butler, J. (1993). Bodies That Matter: On the Discursive Limits of "Sex". New York - London, Routledge.

Campbell, David. 1998. National Deconstruction: Violence, Identity, and Justice in Bosnia. Minneapolis: University of Minneapolis Press. 
Campbell, S., D. Chandler, and M. Sabaratnam. 2011. A Liberal Peace? The Problems and Practices of Peacebuilding. London; New York: Zed Books.

Chandler, David. 2010. "Culture and Civil Society: Peacebuilding Discourse and the Understanding of Difference." Security Dialogue 41 (4): 369-90.

Chesterman, S., M. Ignatieff and R. Thakur (2005). Making States Work: State Failure and the Crisis of Governance. Tokyo, United Nations University Press.

Chesterman, Simon, Michael Ignatieff, and Ramesh Thakur. 2005. Making States Work: State Failure and the Crisis of Governance. Tokyo: United Nations Univeristy Press.

Connolly, William E. 2002. Identity/Difference: Democratic Negotiations of Political Paradox. Expanded ed. Minneapolis; London: University of Minnesota Press.

Doyle, Michael W. 1986. "Liberalism and World Politics." American Political Science Review 80 (4): 1151-1169.

Drichel, Simone. 2008. "The Time of Hybridity." Philosophy \& Social Criticism 34 (6): 587-615.

Eller, Jack D. 1999. From Culture to Ethnicity to Conflict: An Anthropological Perspective on International Ethnic Conflict. Ann Arbor: University of Michigan Press.

Escobar, A. (2008). Territories of Difference: Place, Movements, Life, Redes. Durham and London, Duke University Press

Fukuyama, Francis. 1992. The End of History and the Last Man. New York: Free Press.

Gabay, Clive, and Carl Death. 2012. 'Building States and Civil Societies in Africa: Liberal Interventions and Global Governmentality'. Journal of Intervention and Statebuilding, 6 (1): 1-6.

Ghani, Ashraf, and Clare Lockhart. 2008. Fixing Failed States: A Framework for Rebuilding a Fractured World. Oxford: Oxford University Press.

Hirblinger, A. T. and C. Simons (2015). "The good, the bad, and the powerful: Representations of the 'local' in peacebuilding." Security Dialogue 46(5): 422-439.

Hirblinger, A. and Dana M. Landau (2018), "Governing Conflict: The Politics of Scaling Difference", Journal of Intervention and Statebuilding 12 (3): 385-404.

Huntington, Samuel P. 1991. "Democracy's Third Wave." Journal of Democracy 2 (2): 12-34.

Inayatullah, N. (2016). "Gigging on the World Stage: Bossa Nova and Afrobeat after Dereification." Contexto Internacional 38(2): 523-543.

Inayatullah, N. and D. L. Blaney (2004). International Relations and the Problem of Difference. New York, Routledge.

Ingram, S. (2010) Statebuilding: Key Concepts and Operational Implications in Two Fragile States: The Case of Sierra Leone and Liberia. Washington, DC and New York, NY: The World Bank and UNDP.

Joseph, J. (2018) Beyond Relationalism in Peacebuilding. Journal of Intervention and Statebuilding 12(3): 425-434.

Kappler, S. (2015). "The dynamic local: delocalisation and (re-)localisation in the search for peacebuilding identity." Third World Quarterly 36(5): 875-889.

Krishna, S. (1993). "Review: The Importance of Being Ironic: A Postcolonial View on Critical International Relations Theory." Alternatives: Global, Local, Political 18(3): 385-417.

Kymlicka, Will. 2001. "Reply and Conclusion." In Can Liberal Pluralism Be Exported? Western Political Theory and Ethnic Relations in Eastern Europe, edited by Will Kymlicky and Magda Opalski, 345-414. Oxford: Oxford Univerity Press.

Lapid, Yosef, and Friedrich Kratochwil. 1996. The Return of Culture and Identity in IR Theory. Boulder, CO; London: Lynne Rienner.

Lederach, John P. 1997. Building Peace: Sustainable Reconciliation in Divided Societies. Washington, D.C.: United States Institute of Peace Press.

Lee, S. Y. and A. Özerdem, Eds. (2015). Local Ownership in International Peacebuilding. London and New York, Routledge.

Lemay-Hébert, N. and X. Mathieu (2014). "The oecd's discourse on fragile states: expertise and the normalisation of knowledge production." Third World Quarterly 35(2): 232-251.

Lidén, K., R. Mac Ginty and O. P. Richmond (2009). "Introduction: Beyond Northern 
Epistemologies of Peace: Peacebuilding Reconstructed?" International Peacekeeping 16(5): 587598.

Lottholz, P. (2018), "Old slogans ringing hollow? The legacy of social engineering, statebuilding and the 'dilemma of difference' in (post-) Soviet Kyrgyzstan", Journal of Intervention and Statebuilding 12 (3): 405-424.

Mac Ginty, R. (2015). "Where is the local? Critical localism and peacebuilding." Third World Quarterly 36(5): 840-856.

Mac Ginty, R. and O. P. Richmond (2016). "The fallacy of constructing hybrid political orders: a reappraisal of the hybrid turn in peacebuilding." International Peacekeeping 23(2): 219-239.

Mac Ginty, R. and P. Firchow (2016). "Top-down and bottom-up narratives of peace and conflict " Politics 36(3): 308-323

Martin de Almagro, M. (2018), "Hybrid Clubs: A Feminist Approach to Peacebuilding in the Democratic Republic of Congo", Journal of Intervention and Statebuilding 12 (3): 319-334.

Mathieu, X. (forthcoming), "Critical Peacebuilding and the Dilemma of Difference: The Stigma of the 'Local' and the Quest for Equality", Third World Quarterly.

Maynard, M. (2001). "'Race', Gender and the Concept of 'Difference' in Feminist Thought". Feminism: Critical Concepts in Literary and Cultural Studies. Volume 4: Feminism and the Politics of Difference. M. Evans. London and New York, Routledge: 300-316.

Miall, Hugh, Oliver Ramsbotham, and Tom Woodhouse. 1999. Contemporary Conflict Resolution: The Prevention, Management and Transformations of Deadly Conflicts. Malden, MA; Cambridge: Polity Press.

Minow, M. (1990). Making all the difference: Inclusion, exclusion, and America law. Ithaca, Cornell University Press.

Millar, G. (2018). Engaging Ethnographic Peace Research: Exploring an Approach, 25 (5): 597 609.

Nadarajah, S. and D. Rampton (2015). "The limits of hybridity and the crisis of liberal peace." Review of International Studies 41(1): 49-72.

OECD (2012) International Support to Post-Conflict Transition: Rethinking Policy, Changing Practice. DAC Guidelines and Reference Series. Organisation for Economic Co-operation and Development (OECD) Publishing. http://dx.doi.org/10.1787/9789264168336-en

Orjuela, C. (2008). The Identity Politics of Peacebuilding: Civil Society in War-torn Sri Lanka. New Delhi, Sage.

Paffenholz, T. (2014). "International peacebuilding goes local: analysing Lederach's conflict transformation theory and its ambivalent encounter with 20 years of practice." Peacebuilding 2(1): 11-27.

Paffenholz, T. (2015). "Unpacking the local turn in peacebuilding: a critical assessment towards an agenda for future research." Third World Quarterly 36(5): 857-874.

Paipais, V. (2011). "Self and other in critical international theory: assimilation, incommensurability and the paradox of critique." Review of International Studies 37(1): 121-140.

Paris, R. and T. D. Sisk (2009). The Dilemmas of Statebuilding: Confronting the Contradictions of Postwar Peace Operations. London, Routledge.

Parker, A. and E. K. Sedgwick (1995). "Introduction: Performativity and Performance". Performativity and Performance. A. Parker and E. K. Sedgwick. London, Routledge: 1-18.

Pupavac, Vanessa. 2001. "Therapeutic Governance: Psycho-Social Intervention and Trauma Risk Management.” Disasters 25 (4): 358-372. doi:10.1111/1467-7717.00184.

Randazzo, E. (2016). "The paradoxes of the 'everyday': scrutinising the local turn in peace building." Third World Quarterly 37(8): 1351-1370.

Read, R. (2018), "Embodying Difference: Reading Gender in Women's Memoirs of Humanitarianism", Journal of Intervention and Statebuilding 12 (3): 300-318.

Richmond, Oliver P, and Roger Mac Ginty. 2015. "Where Now for the Critique of the Liberal Peace?" Cooperation and Conflict 50 (2): 171-89. doi:10.1177/0010836714545691. 
Sabaratnam, M. (2017). Decolonizing Intervention: International Intervention in Mozambique (London and New York: Rowman \& Littlefield).

Simons, C. and F. Zanker (2014). "Questioning the Local in Peacebuilding." Working paper of the Priority Programme 1448 of the German Research Foundation(10): Leipzig and Halle

Valbjørn, Morten. 2008. "Before, during and after the Cultural Turn: A 'Baedeker' to IR's Cultural Journey." International Review of Sociology 18 (1): 55-82. doi:10.1080/03906700701823654.

Vaughan-Williams, Nick. 2006. "Towards a Problematisation of the Problematisations That Reduce Northern Ireland to a 'Problem." Critical Review of International Social and Political Philosophy 9 (4): 513-526. doi:10.1080/13698230600941978.

Visoka, G. and O. P. Richmond (2017). "After Liberal Peace? From Failed State-Building to an Emancipatory Peace in Kosovo." International Studies Perspectives 18(1): 110-129. 